\title{
Supranational Bank Supervision in Europe: The Construction of a Credible Watchdog
}

\author{
Jakub Gren, University of Luxembourg \\ David Howarth, University of Luxembourg \\ Lucia Quaglia, University of York ${ }^{1}$
}

\begin{abstract}
Authors' pre-print version
Please cite: Gren, J., Howarth, D. and Quaglia, L. (2015) 'Supranational Bank Supervision in Europe: The Construction of a Credible Watchdog', Journal of Common Market Studies, 53, S1, pp. 181-199; DOI: 10.1111/jcms.12271
\end{abstract}

\section{Introduction}

In 2014, a major development in the history of European integration took place with the start of supranational banking supervision through the Single Supervisory Mechanism (SSM). The creation of the SSM was the first step in the construction of Banking Union. ${ }^{2}$ It was initially proposed in June 2012 by the European Council president (Van Rompuy 2012) and shortly thereafter endorsed by the European Council. The SSM is to be one of four Banking Union components also including: a single rulebook of EU bank regulation; a single framework for the managed resolution of banks and financial institutions; and a common backstop for temporary financial support. The creation of the SSM amounted to a radical initiative to rebuild financial market confidence in both banks and sovereigns - especially in the euro area periphery - to stabilise the national banking systems exposed directly to a vicious circle between the international financial crisis and the euro area's sovereign debt crisis and to reverse the fragmentation of European financial markets (see Howarth and Quaglia 2013).

The European Council agreed to the SSM Regulation in December 2012 which represents a compromise that assigned the European Central Bank (ECB) responsibility 'for the overall effective functioning of the SSM' and 'direct oversight of the euro area banks' (European Council 2012: 2). This supervision however would be 'differentiated' and the ECB would carry it out in 'close cooperation with national supervisory authorities'. Direct ECB supervision (through Joint Supervisory Teams (JSTs)) was to cover those banks with assets exceeding $€ 30$ billion or those whose assets represent at least 20 per cent of their home country's annual GDP. On 4 February 2014, the ECB (2014a) published a list of 128 such banks.

In 2014, five important SSM milestones were reached. First, on 11 March, the ECB published its manual for its Asset Quality Review (AQR) (ECB 2014b). Second, on 16 April, the ECB published its framework regulation for the operation of the SSM (ECB 2014d), putting meat on the bones of the SSM Regulation adopted by Member States in the Council in 2013. Third, in September, the ECB endorsed the SSM Supervisory

\footnotetext{
${ }^{1}$ David Howarth and Lucia Quaglia would like to thank the Luxembourg Fondation Nationale de Recherche which funded Quaglia's stay in Luxembourg during the 201415 academic year and work on this contribution.

${ }^{2}$ The design of the SSM has been subject to legal analysis: notably, Alexander 2015; Ferran and Babis 2015.
} 
Manual and published a Guide to Banking Supervision which had been drawn up by the Work Stream of the ECB Task Force consisting of ECB and experts from National Competent Authorities (NCAs ${ }^{3}$ ) of the SSM. Fourth, on 26 October the ECB published its Comprehensive Assessment of the 128 banks subject to its direct supervision. This Comprehensive Assessment consisted of the ECB's own Asset Quality Review (AQR) of 128 euro area banks and of the European Banking Authority's (EBA's) Stress Tests of 123 banks in twenty-two European Economic Area (EEA) states. Fifth, the SSM officially began operation on 4 November, the date on which the ECB assumed full control of the prudential supervision of 128 euro area banks.

This contribution focuses on the essential matter of the SSM's credibility - in terms of its institutional and operational design and its first assessment of the stability of systemically important (significant) European banks. What added value does the SSM provide over national supervision? Officially, the SSM is supposed to ensure the more effective supervision of all euro area headquartered banks and notably those institutions subject to the direct ECB supervision because they meet the criteria set by the ECB to be classified as systemically important. The creation of the SSM was also part of a Banking Union package that includes fiscal support for banks deemed to be solvent and a supranational resolution mechanism for those not. Banking Union was designed to help tackle the sovereign debt crisis by addressing the sovereign debt bank doom loop that affected the euro periphery Member States. Thus, the broader effectiveness of the SSM - both in terms of good supervision and broader financial stability — can only be judged in the future and hinges on a number of factors, some of which have little to do with the design and operation of the SSM itself.

This contribution seeks to answer a more modest but nonetheless essential question: does the institutional design of the SSM and its first assessment of systemically important bank stability bolster the credibility of supranational banking supervision in Europe? One crucial measure of credibility with regard to the SSM and NCA supervision of less significant banks - the large majority of euro area headquartered bank not subject to direct ECB supervision - is the assurance of consistent supervision in the euro area. This involves some degree of convergence of NCA supervision in order to prevent national supervisory forebearance of struggling banks. It therefore becomes necessary to examine whether or not the design of the SSM provides the foundation to build convergence in euro area supervision of less significant banks, despite very different national supervisory practices and institutional frameworks. The first section below assesses the credibility of the SSM design in terms of providing the foundation for consistent supervision with the help of the Principal-Agent approach.

The second section of this contribution examines the credibility of the ECB's direct supervision of significant banks. The management of the ECB's Comprehensive Assessment of signficant banks can be seen as the first step in demonstrating the capacity of the ECB to make difficult decisions with regard to the stability of the euro area's banks. Other measures by which to judge the credibility of the SSM are difficult

\footnotetext{
3 'National Competent Authorities' (the NCAs) is a term used in the supervisory acquis to refer to national authorities responsible for banking (depending on given bank supervision arrangements at the national level in different EU Member States). For an overview of (pre-crisis) EU national supervisory architectures see, for example, Masciandaro, (2004), Masciandaro and Pellegrina (2008).
} 
to evaluate. The quality of the supervisory process agreed in the SSM's Supervisory Manual remains largely unknown. Ultimately, avoiding bank failure may be the best gauge of SSM credibility (as in Barth et al. 2006). However, bank resolution through the SRM rather than bank bail-out with either national or European funds might lend more credibility to the SSM. Many expert observers want banks in Europe to be resolved as frequently and unproblematically as in the United States (see Goldstein and Veron 2011). These are measures to debate in the context of future evaluations of the SSM. This contribution seeks to determine if the SSM has begun the unprecedented adventure of supranational banking supervision on the right foot.

\section{Credibility of Institutional Design: ensuring the consistent supervision of less significant banks}

A significant part of the credibility of the SSM's institutional design has been about designing 'ex ante' and 'ex post' controls by the Single Supervisory Board (SSB) of the ECB over the NCAs in order to ensure a degree of consistency in supervisory practice. These controls can be understood through an application of the PrincipalAgent analytical framework (Weingast and Moran 1983, Kiewiet and McCubbins 1991, Pollack 1997; Thatcher and Stone Sweet 2002: 5). The ECB can be seen as a principal that adopts a range of controls to ensure that its policy preferences are enforced by the NCAs within the SSM. It then becomes important to assess whether these controls cover all of 'zones of discretion' ${ }^{4}$ the NCAs have with regard to supervisory tasks ${ }^{5}$ which they carry out on the ECB's behalf. The credibility of the SSM design thus depends upon limiting the NCAs' 'zone of discretion' (what we refer to as 'black holes'). Clearly, in relation to the existing application of the Principal-Agent framework in national or European Union contexts, it is unusual to treat the nonmajoritarian, but independent, ECB as a principal and the non-majoritarian national supervisors (NCAs), selected by national governments, as agents of the ECB. In the vast majority of political science studies, a government or governments are treated as the principal / collective principal. With regard to EU policy making, Principal-Agent analysis has been applied to improve our understanding of the relations between EU Member States and the Commission and the ability of the former to control the latter (Pollack 1997); it has also been applied to examine the relations between the Member States and the European Central Bank, with the focus on the limited ex ante and ex post controls of the principals over the ECB agent (Elgie 2002). The Principal-Agent approach has also been used to explain the relations between EU Member States and the Council of Ministers (Ecofin) and notably in the area of the EU fiscal governance (Schuknecht 2004; Hodson 2009). However, to date, the application of Principal-Agent analysis to the relations between EU institutions and other agencies / authorities has

${ }^{4}$ To define a 'zone of discretion' this contribution employs the understanding developed by Thatcher and Stone Sweet (2002). The zone of discretion is 'the sum of delegated powers (policy discretion) granted by the principal to the agent, minus (b) the sum of control instruments, available for use by the principals to shape (constrain) or annul (reverse) policy outcomes that emerge as a result of the agent's performance of set tasks' (ibid: 5).

${ }^{5}$ For the sake of brevity, 'supervisory tasks' are understood in this contribution as specific tasks concerning policies relating to the prudential supervision of credit institutions in accordance with the SSM Regulation (Council 2013). 
been limited (see, for example, Thatcher 2011; and Eneberg and Trondal 2011). On the application of a Principal-Agent analysis to the relations between two non-majoritarian institutions / bodies see Waterman and Meier (1998) and Terman (2015).

At the national level, with regard to banking supervision, Principal-Agent analysis has been conducted by a number of scholars to explore the incentive problems of bank supervisors acting as agents of national taxpayers (see, for example, Schuler 2003) and to examine the financing of bank supervision where society acts as the principal and the banking supervisory authority as the agent (Masciandaro et al. 2007). PrincipalAgent analysis has also been applied to explain policymakers' decisions on the institutional design of bank supervision (in a comparative context see Masciandaro 2004) and to understand the extent to which power is consolidated in financial supervision (Masciandaro and Pellegrina 2008).

In the context of the SSM, three potential principal-agent relationships arise: between Member State governments (collectively) and the ECB (and its Single Supervisory Board (SSB)); between Member State governments (individually) and NCAs; ${ }^{6}$ and between the ECB and NCAs. It is the latter on which we focus here given that the independence of both the ECB/SSB and NCAs is a starting point of the SSM although it is very likely that NCA autonomy from Member State governments in the years to come will be tested especially when politically difficult decisions over bank mergers and resolution arise. While EU Member States assigned powers to the ECB over supervision in the context of the SSM regulation, they imposed no specific institutional framework to govern the relationship of the ECB and NCAs. Therefore, the ECB had a very large margin of manoeuvre in designing this framework. The focus of this section is on the likelihood of the SSM design resulting in consistency in supervision and thus most relevant is the principal-agent relationship between the ECB and the NCAs which carry out certain supervisory tasks on behalf of the ECB. As the ECB is solely responsible for the efficient functioning of the SSM, its relations with the NCAs are pivotal, in particular with regard to ensuring the ECB's supervisory policy preferences within the system.

The basic design of the SSM is outlined in its founding act: the SSM Regulation (Council 2013). In light of this regulation, the SSM is a primarily ${ }^{7}$ euro area banking supervisory system (regime) consisting of the ECB and NCAs (of euro area Member States) as bank supervisors (Council 2013, article 6.1). The overarching objective of the SSM, for which the ECB is solely responsible (ibid.), is to ensure that all banks of the Member States participating in the system are subjected to supervision of the highest quality implemented in a coherent and effective manner (Council 2013, recital 12). The SSM Regulation provides for two supervisory procedures relating to the euro

\footnotetext{
${ }^{6}$ The SSM Regulation provides no legal underpinning for the delegation of powers to the NCAs. Therefore, in the context of the operation of the SSM, the relationship between Member State governments and the NCAs has no direct legal basis per se. Nonetheless, NCAs remain agents of Member State governments in that they are appointed by them and, in terms of national politics, they remain de facto accountable to them with regard to their supervisory activities.

${ }^{7}$ The SSM Regulation provides the possibility for non-euro area Member States to optin to a framework of 'close cooperation'. The modalities of the 'close cooperation' regime are detailed in Part IX of the SSM Framework Regulation (ECB 2014d).
} 
area banks in the SSM framework: the direct ECB's supervision of the significant banks (Council 2013, article 6.4) and the direct NCAs' supervision of the less significant banks (Council 2013, article 6.5) under the ECB's oversight (indirect ECB supervision). Delegation of supervisory tasks with regard to less significant banks applies to the relationship between the ECB and the NCAs in a following way: ${ }^{8}$ as the ECB is solely responsible for effective and consistent functioning of the SSM, all the supervisory tasks carried out within the SSM are ones carried out on the account and on behalf of the ECB. Thus, it follows that all the supervisory tasks, notably supervision of less significant banks, are executed by the NCAs in the SSM on behalf of the ECB.

From a rationalist perspective, the ECB's core underlying interest is to ensure its control over supervision. From this stems a second interest: to ensure effective supervision although the measurement of this is potentially difficult as noted above. From these interests stem the preference of consistent, and thus largely convergent, supervision. Many EU Member State governments accepted the legitimacy of these interests and preference because they accepted, at least in part, the argument that the financial crisis in the EU was exacerbated by the fragmentation in the supervision of large cross-border banks - in addition to ineffective 'light touch' regulation and supervision in some Member States - and national supervisory bias - and notably the tendency to demonstrate 'forbearance' towards 'national champions'. ${ }^{9}$ If we are to interpret the foundation of the SSM as a decisive EU post-crisis measure, this suggests that the ECB's interest in the SSM framework should be to mitigate the factors which contributed to the impact of the recent financial crisis in the EU and to ensure the highest quality supervision. This interest - like that of ensuring ECB control - results in the preferences of reducing the scope of national supervisory divergence and eradicating the remaining national bias amongst NCAs.

\section{The ECB's mechanisms of control over the NCAs}

Even when the principal's policy preferences are clearly articulated, an agent should be seen as rational and opportunistic and capable of developing its own preferences (Ross 1973; Kiewet, McCubbins 1991). The inherently asymmetrical distribution of information in a principal-agent relation favours the agent and creates perverse incentives for the agent to pursue its own preferences (Holmstrom 1979, Kiewiet and McCubbins 1991). In cases where agent preferences diverge from those of the principal, 'agency loss' occurs and an agent 'shirks'. The potential for agent 'slippage' deliberate 'shirking' — can be created by the very structure of political delegation (Pollack 1997). Therefore, the principal must find ways to limit potential 'shirking' by

\footnotetext{
${ }^{8}$ The case of the SSM is a rare one where a political delegation is not formally followed by a legal delegation of tasks. In legal terms, no delegation between the ECB and the NCAs de jure occurs and the SSM is treated as 'separate business line' of the ECB with two different supervisory approaches: a direct one to significant banks and indirect one to less significant banks. Yet this lack of legal delegation remains controversial both in policy making circles and in the legal academic community. See, for example, the analysis of Ferranini and Chiarella (2013) who describe the ECB-NCAs relations in terms of delegation, and Wymeersch (2014) who does not accept that delegation has occurred.

${ }^{9}$ For example, the Bundesbank in its October Monthly Report (2014: 44) argued that the SSM 'will minimise the hazards of potentially inappropriate supervisory forbearance guided by national interests (known as "home bias")'.
} 
developing controls that encourage agent compliance with the principal's policy choices and discourage the creation of incentives for the agent to 'slip'.

The principal-agent relationship between the ECB and the NCAs in the SSM relating to supervision of less significant banks is likely to contribute to NCA slippage, because the SSM Regulation confers on the ECB only the responsibility for its efficient and consistent functioning. ECB-NCA relations are principally designed as 'relations of information' (ECB 2014c) (in the words of the SSM Framework Regulation makers ${ }^{10}$ ). The principal focus of the ECB is upon significant banks (ECB 2015). ${ }^{11}$ The interpretation of necessary consistency and degree of convergence in the supervision of less significant banks remains subject to different views amongst supervisors themselves. The former head of BAFIN, the German federal banking supervisor, Elke Koenig (who was subsequently appointed to Chair the Single Resolution Board based in Frankfurt) has repeatedly made clear her view that divergence in the supervision of less significant banks at the national level will continue in the immediate future given very different national institutional and regulatory frameworks - although she noted that harmonization would take place gradually and in the long term. In a clear assertion of ongoing NCA autonomy, Koenig even stated that the ECB's specific decisions on the supervision of less significant banks would not be binding upon NCAs (Koenig 2014).

Principal-Agent analysis outlines two groups of mechanisms adopted to mitigate the agent 'shirking' and ensure agent alignment with the principal's policy preferences. These are the 'ex-ante' and the 'ex-post' controls. As these controls are not costless measures their usage is ultimately a trade-off between higher agency costs and limiting of the 'agency loss'. Here we examine the 'ex ante' and the 'ex post' controls assigned to the ECB in relation to NCA supervision of less significant banks within the SSM framework and their likely effectiveness.

The principal's 'ex-ante' controls, also known as administrative procedures, define the scope of agency, legal instruments available for the agent and the set of procedures the agent must follow (Pollack, 1997). These instruments and procedures delineate the agent's room to manoeuvre as to the execution of discretionary powers. The institutional design of the SSM provides a number of the ECB's 'ex-ante' controls over the NCAs which are outlined in the SSM Framework Regulation, the Supervisory Manual, ${ }^{12}$ the SSM common supervisory procedures, and the NCAs' 'ex-ante'

${ }^{10}$ Eduard Fernandez-Bollo (Chairman of the ECB's work stream (WS2) on the SSM legal framework and Ignazio Angeloni (Chair of DG Macro-Prudential Policy and Financial Stability at the ECB) at the ECB's Public Hearing on the SSM Framework Regulation, 19 February 2014, Frankfurt.

${ }^{11}$ Such a conclusion may be drawn after an overview of the SSM global governance structure in the ECB: two DGs (DG Micro I and II with around 15 Divisions for direct supervision of the significant banks and one DG (Micro III) with only 3 Divisions for indirect supervision of the less significant banks. See the organigramme of the SSM (ECB 2015).

12 The ECB Supervisory Manual is an internal and partially confidential ECB/SSM document addressed to the NCAs, covering all the tasks and supervisory processes of the SSM. As such, it complements both the SSM Regulation and the future SSM 
reporting on 'material' decisions and procedures - that is, decisions and procedures that are of supervisory interest to the ECB. The ECB's power to issue regulations, guidelines and general instructions for the NCAs can be regarded as a mechanism situated in between the 'ex ante' and the 'ex post' controls (and is thus discussed below).

In the SSM Regulation (Council 2013, article 6(7)), EU Member States assigned the ECB the obligation to establish the modalities of ECB-NCA relations - which, as noted above, allows us to treat the ECB as a principal. The single supervisory approach, which is both to precede and shape national supervisory practice, is outlined in the ECB's Framework Regulation and in the Supervisory Manual. The Framework Regulation divides supervisory tasks within the SSM. The Supervisory Manual provides more specific details as to the ECB-NCAs' non-public and confidential relationship in managing the supervision of less significant banks. These two documents set limits on the NCAs' discretion and may be considered as the ECB's 'exante' controls (procedures) on the NCAs' supervisory policies, aimed at ensuring the ECB's policy preference of reducing national divergence in supervisory approaches and eradicating the remaining national bias in supervisory practices.

Even though the SSM regulation assigns to the ECB direct supervisory powers only over more significant banks, the ECB's Framework Regulation (ECB 2014d) stipulates a number of specific supervisory powers which are a direct and exclusive competence of the ECB with regard to all banks, both significant and less significant. These powers are listed in Part V of the SSM Framework Regulation and described as 'Common Procedures'. The SSM common supervisory procedures encompass: bank authorization (ECB 2014d, articles 73-79), withdrawal of bank authorizations (ECB 2014d, articles 80-84), and assessment of the acquisition of a qualifying holding (ECB 2014d, articles 85-87). The role of the NCAs in these procedures is limited to serving as an 'entry point', as in the case of bank authorizations, or to initiating the procedure and nonbinding consultations, as with regard to withdrawals of bank authorizations and assessments of the acquisitions of qualifying holdings. The SSM common supervisory procedures are an example of the principal's involvement in important decision-making on the less significant banks and as such constitute 'ex-ante' controls on the agents' discretion in key supervisory policies.

The SSM Framework Regulation obliges the NCAs to report ex ante - or, exceptionally, simultaneously - on 'material' supervisory procedures concerning the less significant banks (ECB 2014d, article 97). The ECB is empowered to provide opinions on the draft material decisions and procedure, for example: the removal of bank management board members, the appointment of a receiver (ECB 2014d, art. 97 (2a)) and the procedures which have a 'significant impact' on a less significant bank (ECB 2014d, art. 97 (2b)). The ECB shall define the general criteria for 'significant impact', based on the risk situation of the bank and the potential impact on the domestic financial system. As these NCA 'ex-ante' reporting requirements on 'materiality' impose a burden on the execution of their discretionary powers, these requirements may be perceived in terms of the principal's 'ex-ante' controls, which enable the ECB to oversee NCA actions.

Framework Regulation and constitutes an important part of common supervisory acquis. 
In addition to these procedures, in which 'materiality' is defined either by law or at the ECB's discretion, the SSM Framework Regulation envisages another NCA 'ex ante' reporting procedure, the initialization of which is however at the NCAs' discretion. In cases where a NCA finds a procedure either to be 'material' and thus of supervisory interest for the ECB (ECB 2014d, article 97) or potentially to affect negatively the reputation of the SSM (ECB 2014d, article 97(4b)), the NCA can notify the ECB as such. According to the drafters' own interpretation, this procedure should be treated as a 'catch-up' clause for those NCA decisions which 'do not fulfill the "materiality" premises, but should be assessed by the NCAs with regard to the quantitative criteria' (ECB 2014c). In the context of a Principal-Agent analysis, this NCA power of initiative may be problematic in that it potentially generates 'leaks' in the principal's control of its agents' 'zone of discretion'. The NCAs have the power to delineate the border between 'material' and 'non-material' procedures; that is, they can decide which supervisory procedures shall be of interest to the ECB and carry the burden of the ex ante oversight and which shall not. This issue is examined further below.

According to art. 6 (5a) of the SSM Regulation (Council 2013), the ECB has a power to issue regulations, guidelines and general instructions to the NCAs with regard to all supervisory tasks carried out by them within the SSM, with the exception of the common supervisory procedures. From the perspective of Principal-Agent analysis, these instruments can be regarded as both 'ex-ante' and 'ex-post' ('hybrid') controls depending on the given circumstances. The role of these ECB guidelines is principally to inform the NCAs how certain provisions of the supervisory acquis should be interpreted and applied and how the NCAs should use their discretionary powers. The ECB's regulations and general instructions, in turn, are to steer the NCAs' supervisory actions. For example, the Supervisory Manual, which is - in substance - a guideline on the supervisory policies within the SSM, could be described as an 'ex-ante' control. However, an instruction directed by the ECB to a NCA would be an example of 'ex post' control (ECB 2014d, article 108). Given the sensitivity of banking supervision and its potential impact on financial markets, many of the ECB's regulations, guidelines and instructions directed to NCAs will be of confidential nature and are likely to be (only partially) disclosed after a certain period of time (Interviews, CSSF ${ }^{13}$, Luxembourg, February/March 2014).

The legal status of the ECB's regulations, guidelines and general instructions directed to the NCAs remains however ambiguous. In light of article $288 \mathrm{TFEU}^{14}$ and article 34 of the ECB Statute, in order to exercise the Union's competences, the ECB can adopt legally binding regulations, directives, decisions and non-binding recommendations and opinions. Regulations are legally binding in their entirety as well as generally and directly applicable in all Member States and by its administrative bodies. Directives are legally binding upon Member States only and with regard to the policy result to be achieved, leaving to national authorities free choice as to forms and methods. Decisions are legally binding in their entirety, but only to those whom they address. All five of

\footnotetext{
${ }^{13}$ The Commission de Surveillance du Secteur Financier (CSSF) is Luxembourg's national authority competent for banking supervision within the SSM.

${ }^{14}$ Treaty on the Functioning of the European Union - one of the EU constitutional treaties; available at http://bit.ly/P99UhB; accessed 31 March 2014.
} 
the abovementioned acts are known as EU 'typical acts'. The other decision-making instruments of the EU institutions not expressly listed in article 288 TFEU, are generally referred to as EU 'atypical acts' (see, for example, Snyder 1993; Cosma and Whish 2003; Grosse Ruse-Khan et al. 2011). The catalogue of decision-making atypical acts available to the EU institutions is open-ended and covers such instruments as inter-institutional agreements ${ }^{15}$, guidelines ${ }^{16}$ and guiding directives. ${ }^{17}$ It follows that the ECB's regulations, guidelines and general instructions directed to the NCAs with regard to supervision of less significant banks may be seen to be equivalent to EU atypical acts. This issue, and particularly the problem of the enforceability of these ECB regulations, guidelines and general instructions, is explored further below.

The ECB's 'ex post' controls over the NCAs

The principal's 'ex post' controls, known also as oversight procedures, allow the principal to monitor its agent's behaviour and impose sanctions in the event of 'agency shirking'. These 'ex-post' controls are conventionally divided into 'police patrols' and 'fire-alarms' (Kiewet and McCubbins, 1991). 'Police patrols' consist of an active surveillance of a sample of the agent's behavior by the principal with the aim of detecting any of their non-compliance with the principal's policy preferences. In a classic form they include public hearings, studies, field observations and examinations of regular agent reports (Pollack, 1997). 'Fire alarms' are the principal's indirect 'ex post' controls because, while monitoring agents' activities, the principal relies on the support of third parties. 'Fire alarms' are less costly but at the same time, they are also less centralized and tend to be more superficial than 'police patrols'.

\section{ECB police patrols}

Among the 'police patrols', which the ECB has at its disposal to oversee NCA compliance with its policy preferences, three are particularly important: the NCAs' 'ex-post' reporting requirements; the ECB's power to request supervisory information from any less significant banks and to conduct general investigations and send on-site inspections to any less significant bank; and ultimately the ECB's power to take over the supervision of the less significant bank from the NCA. 'Police patrols' can be 'intrusive' or 'non-intrusive'. The latter may, in turn, be tentatively divided into 'yellow card' police patrols and 'red card' police patrols.

The NCAs' 'ex-post' reporting requirements can be seen as instruments of the ECB's 'non-intrusive police patrols'. Articles 99 and 100 of the SSM Framework Regulation (ECB 2014d) obliges the NCAs to submit regular reports on their supervisory activities regarding the less significant banks on the basis of which the ECB will assess the degree of the NCAs compliance with its policy preferences. Furthermore, the NCAs may be requested to provide information on their supervisory activities, both on an ad hoc or continual basis (Council 2013, article 6 (5e)).

The ECB's 'intrusive police patrols' include presenting a 'yellow card' to a NCA following its problematic supervision of a less significant bank. The section 'Investigatory Powers' of Chapter Three of the SSM Regulation (Council 2013)

\footnotetext{
${ }^{15}$ For e.g., see TFEU art. 177, 287(3), and 295 TFEU.

${ }^{16}$ For e.g. see ibid. art. 121(2), 148(2), or 171(1).

${ }^{17}$ For e.g., see ibid. art. 218(2).
} 
stipulates three procedures which can be classified as field observations (both on- and offsite) and can be treated as examples of 'yellow card' police patrols. These are: the ECB's power to request supervisory information directly from less significant banks (Council 2013, article 10); and the ECB's powers to carry out general investigations (Council 2013, article 11) and on-site inspections (Council 2013, article 12). These procedures are completely separate from the NCA's 'ex ante' reporting on less significant banks. An ECB on-site inspection must notified to the concerned NCA at least one week prior to the notification of the less significant bank concerned (ECB 2014d, article 145). Yet the ECB may decide that a less significant bank should not be informed about a planned on-site inspection if it could jeopardise the efficiency and proper conduct of an on-site inspection (ECB 2014d, article 145). The detailed procedures relating to the ECB's on-site inspections have been further outlined in the Supervisory Manual but remain closed to the public.

The second level of ECB 'intrusive police patrols' involves assigning a 'red card' to NCAs on the grounds of unacceptable performance relating to the supervision of less significant banks. The 'red card' results in direct ECB intervention into the NCAs' zone of discretion, with a view to reverse and improve the outcomes of their supervisory policies. The SSM Regulation (Council 2013, article 6 (5b)) provides the ECB the power, on its own initiative, ${ }^{18}$ to take over from a NCA direct supervision of a particular less significant bank to ensure the consistent application of high supervisory standards (the 'take-over' clause).

\section{ECB fire alarms}

The SSM Regulation (Council 2013) assigns the ECB also possesses both 'internal' and 'external' 'fire-alarms' to prevent agent shirking. The ECB's power to relocate national supervisory personnel among the different NCAs participating in the SSM can be seen as an 'internal' 'fire alarm' in that the procedure is foreseen with the framework of the SSM and no external institutions are engaged. This power can also be in part characterized as a 'police patrol' control. The ECB may find it 'appropriate' to involve staff from one NCA into supervisory teams of another NCA in order to interfere with the direct supervision of less significant banks (Council 2013, article 31(2)). The vague wording of the SSM Regulation enabling clause for this ex-post control gives the ECB considerable margin of manoeuvre in its interpretation and application. The ECB can make use of this control in order to ensure that its policy preference is followed by the agent, allowing the ECB to avoid having to make use of more centralized 'police patrols' controls. In this case, the personnel of one SSM NCA monitors the manner in which another NCA carries out its supervisory tasks. The ECB thus acquires a decentralized source of information on possible agency shirking / slippage on the part of the NCAs. A caveat to treating this mechanism as a 'fire-alarm' stems from the fact that personnel from another agent (or other agents) (and not a 'third party' per se) engage in the monitoring. The SSM consists of a single principal (the ECB) but multiple agents (NCAs) and, in this context, it may be justified to treat national supervisory staff of one NCA involved in the work of another NCA as the equivalent to a 'third party' in this context. As the NCAs may compete among themselves for reputational reasons and for favours from their principal, it should not be assumed that NCA personnel will succumb to supervisory forbearance (and thus contribute to agency 'slippage') when engaged in the supervisory work of their fellow NCAs.

\footnotetext{
${ }^{18}$ But also upon request by a NCA (see Council 2013).
} 
'External' 'fire alarms' are forms of decentralized oversight exercised by bodies that are external to the SSM framework (see, for example, Kiewet and McCubbins 1991). Two 'external' 'fire alarms' regarding the operation of NCAs can be identified. First, the European Banking Authority (EBA) has the power to identify breaches of EU law by NCAs. According to article 17 of the EBA Regulation (Council and European Parliament 2010), the EBA shall counteract the breaches of EU law by competent authorities which means that the EBA is empowered to examine the conformity of actions of the NCAs (and the ECB) with the SSM Regulation, the SSM Framework Regulation and other EU legal acts (on both hard and soft law and on supervisory or regulatory matters). The second main 'external' 'fire alarm' is that national parliaments can request public hearings on SSM supervisory policies involving personnel from both the ECB's supervisory arm and the NCA concerned. On the supervision of less significant banks in the SSM, NCAs may be called to account by national parliaments in two ways. First, a NCA representative may be invited together with the Chair or other member of the SSM's Supervisory Board to participate in an 'exchange of views' on supervisory policies and supervision (Council 2013, article 21 (3)). Therefore, such an 'exchange of views' may also address the supervision of less significant banks in various contexts. This mechanism may be useful for the ECB to assess in an ad hoc manner the supervisory approach of a particular NCA and its conformity with its policy preferences. Second, the SSM Regulation maintains national parliamentary oversight over NCAs, even with regard to their tasks carried out within the SSM (Council 2013, art. 21 (4)). This national-level 'external' 'fire-alarm', as with EBA judicial oversight can bring agency discretion to the attention of the ECB principal.

\section{The ECB's struggle ahead to ensure its policy preferences}

The ECB's mechanisms of control outlined above do not cover all the 'zones of discretion' that the NCAs enjoy when carrying out the direct supervision of less significant banks on behalf of the ECB. There are three major challenges to the maintenance of the ECB's preferences that stem from the SSM's current institutional design: the NCAs discretion on 'materiality' reporting (in particular the usage of the 'catch-up clause'); the legal status of the ECB's regulations, guidelines and instructions directed to the NCAs; and the 'proportional' application of the SSM Regulation and the ECB's Framework Regulation to the supervision of less significant banks. As noted above, the NCAs are required to notify 'ex ante' the ECB on a supervisory procedure which they consider to be 'material' and thus of potential supervisory interest to the ECB (ECB 2014d, article 97 (4a)) or which may negatively affect the reputation of the SSM (ibid., article 97 (4b)). The ECB added this provision into the Framework Regulation in order to enable the ECB to be informed on the major developments affecting less significant banks - which is clearly important in terms of ensuring the ECB's policy preferences. However, NCAs retain the power to determine whether or not a procedure is 'material' and thus of potential supervisory interest to the ECB.

The confidential and undisclosed regulations, supervisory guidelines and instructions that the ECB is empowered to adopt in relation to the NCAs (permitted under article 288 TFEU) are commonly referred to as 'atypical acts'. However, neither the SSM Regulation nor the Framework Regulation provides the ECB with direct instruments to enforce these regulations, guidelines and general instructions (Wymeersch 2014: 41) - with the important exception of the 'take-over clause' which might well be seen as the 'nuclear option' in the context of the SSM. Although, their legally binding nature 
is evident, it is unlikely that confidential regulations, guidelines and instructions will be enforced with a direct and hard mechanism. ${ }^{19}$ It follows, therefore, that these measures cannot be considered to be 'hard law' - that is, a legal situation where a hard legal obligation is followed by a hard enforcement mechanism (Terpan 2015: 13). The NCAs' legal obligations are not formally accompanied by coercive mechanisms to ensure their enforcement. Therefore, it is prudent to consider the ECB's confidential and undisclosed regulations, guidelines and general instructions as 'soft law' or 'soft atypical acts'. In summary, the ECB lacks the power to give binding instructions (or equivalent acts) to NCAs regarding the supervision of specific less significant banks in specific cases.

The principle of proportionality (article 5 of TEU) applies to the operation of the SSM. The drafters of the SSM Framework Regulation claimed that the less significant banks would have simplified reporting requirements in comparison to significant banks. Also the risk management standards enshrined in the supervisory acquis will be proportionally applied to the less significant banks (ECB 2014c). ${ }^{20}$ Although proportionality may be necessary to simplify the supervision in the SSM (ibid. $)^{21}$, the application of the principle gives the NCAs 'margin of discretion' and effectively undermines the ECB's policy preference of consistency in supervisory approach. Therefore, it is crucial for the ECB to define necessary ex ante guidelines for the NCAs on how to interpret the common supervisory acquis.

\section{The Credibility of ECB Supervision of Significant Banks: The Comprehensive Assessment}

The credibility of the SSM's supervision of the 128 significant banks in the euro area depends upon the institutional design of supervision and the supervisory rules and procedures. Clearly, there are a number of persistent concerns as to the potential effectiveness of: the design of the Joint Supervisory Teams (JSTs); the ability of a limited number of ECB supervisory staff to ensure adequate centralized control within the JSTs; and the precise supervisory model adopted (only part of which has been disclosed to the public in the Supervisory Manual). However, without the precedent of supranational supervision and without the hindsight of several years of operation, there are no objective gauges to evaluate effectively the credibility of the SSM supervision of significant banks. As the first important undertaking by the SSM, the ECB's Comprehensive Assessment of 128 systemically important euro area banks - holding 81.6 per cent of all euro area assets - should be examined in terms of its contribution to the credibility of supranational bank supervision. The Comprehensive Assessment, undertaken in the summer and autumn of 2014, assumed a symbolic importance as to the future effectiveness of the SSM. ${ }^{22}$ In this section we consider the importance of the

${ }^{19}$ A 'hard enforcement mechanism' is a legal situation in which compliance with the rules is ensured by judicial or (exceptionally) administrative review. For an overview on this matter see Terpan (2013).

${ }^{20}$ Jukka Vessala (Director of DG Micro III) at the ECB's Public Hearing on the SSM Framework Regulation, 19 February 2014, Frankfurt; see ECB (2014c).

${ }^{21}$ Ignazio Angeloni (Director of DG Macro-Prudential Policy and Financial Stability of the ECB) at the ECB's Public Hearing on the SSM Framework Regulation, 19 February 2014, Frankfurt; see ECB (2014c)

22 'Stakes high for Europe's bank stress tests', Financial Times, 22 October 2014. 
Comprehensive Assessment and the reaction of the financial press, financial market operators (notably credit rating agencies) and leading financial economists.

The Comprehensive Assessment consisted of the Asset Quality Review (AQR) undertaken by the ECB of a total of 128 euro area headquartered banks based on data from the end of December 2013 — and stress tests of 123 EEA headquartered banks conducted by the EBA. Information gained in the former was intended to feed into the latter. ${ }^{23}$ Both the AQR and stress tests required banks to hold at least eight per cent of regulatory capital - consisting principally of equity and retained earnings - in relation to their risk-weighted assets under transitional Basel III / EU CRDIV rules. The publication of the AQR and the stress tests on the same day - 26 October - by two different bodies, on a different but largely overlapping sample of banks, created the potential for confusion (de Groen and Lannoo 2014). ${ }^{24}$ For the ECB, the AQR and broader Comprehensive Assessment was a matter of establishing its credibility as a supranational bank supervisor. For the EBA, the 2014 stress tests were a matter of restoring the confidence the Authority lost in the 2011 tests - widely criticized on the grounds that they offered a seriously inadequate assessment of the ability of European banks to withstand a major financial crisis (Buckley et al. 2012). ${ }^{25}$ Infamously, the Franco-Belgian bank Dexia had to be bailed-out in November 2012 for a third time in four years and less than a year after having passed the EBA's 2011 stress tests. The ability of the ECB and EBA to work together in the future in a manner that reinforced the credibility of supranational banking supervision remained to be seen (Wymeersch 2014).

The AQR became necessary because of German government insistence that banks with 'legacy problems' must not be assisted with European Stability Mechanism (ESM) bailout funds. ${ }^{26}$ However, even without German insistence, a review of the assets of the euro area's largest banks could help - if undertaken with sufficient objective rigour - to bolster the credibility of the SSM and the role of the ECB as a new microprudential authority. To defenders, the AQR provided unprecedented scrutiny of bank loan books and collateral portfolios. The AQR involved over six thousand ECB and NCA officials, reviewing eight hundred portfolios, amounting to more than 57 per cent of the risk-weighted assets of the 128 banks examined. The ECB also stated that officials examined 119,000 borrowers, valued 170,000 items of collateral, build 765 models to challenge banks' own estimates of risk-weighted assets (ECB 2014e: 19). ${ }^{27}$ It provided a great deal of data that supervisors and private bank analysts could closely examine. Crucially, the AQR significantly improved the transparency and comparability of bank data across the eighteen euro area Member States and Lithuania (to join at the start 2015). The AQR manual (ECB 2014b), published on 11 March,

\footnotetext{
${ }^{23}$ De Groen and Lannoo (2014) examine the relationship between the ECB's AQR and the EBA's stress tests of largely overlapping but slightly different groups. See also 'ECB says bank asset reviews will feed into stress tests', Financial Times, 8 August 2014.

${ }^{24}$ De Groen and Lannoo (2014) show that only 103 banks were subject to both the AQR and the stress tests. Twenty banks were subject to the stress bank, while twenty-seven banks were subject to the AQR and not the stress tests.

${ }^{25}$ Financial Times, 27 October 2014.

${ }^{26}$ EUObserver, 3 December 2012.

27 'ECB says banks overvalued assets by €48bn'. Financial Times, 26 October 2014.
} 
included the first set of bank supervision guidelines ever produced for, specifically, euro area NCAs - which were considerably more detailed and directing than existing EBA guidelines. The manual contains methodology for the AQR's 'phase 2' (the onsite inspection of banks) with detailed guidance on a range of matters including: procedures for validating data and checking model inputs; the valuation of material exposures and collateral and determine provisioning needs; the processes for quality assurance and progress tracking to ensure timely completion; when to use independent, external valuations for assets; and the use of industry benchmarks to assess market values. The AQR harmonized the definition of non-performing loans and uncovered hidden losses. In doing so, the ECB found massive shortfalls - $€ 136$ billion - in the loans that banks and national regulators classified as non-performing (bad). This figure amounted to fifteen per cent increase of the total announced by NCAs. The ECB found that banks had over-valued their assets by a total of $€ 48$ billion, pointing especially to an over-valuation of commercial loans. ${ }^{28}$

The success of the EBA's 2014 stress tests can be evaluated by three measures. ${ }^{29}$ The first was sufficient transparency and comparability in the results. In 2014, there were to be twelve thousand data points on the different scenarios (benchmark and adverse) and the EBA made use of AQR definitions. Earlier in the year, the EBA announced that for the first time it would publish fully loaded common equity tier one ratios for each bank - whereas some market participants had previously refused to disclose these figures themselves. Second, rigorous tests could boost confidence in the capital position of European banks. ${ }^{30}$ The 2014 stress tests lowered Tier 1 capital by, on average, four points - even more than US Federal Reserve tests (2.9 per cent drop for participating banks in 2014). Both the ECB president, Mario Draghi, and the head of the SSM, Danièle Nouy, argued publicly that some banks would have to fail the stress tests in order to ensure the credibility of the new system. ${ }^{31}$ Indeed, the number of banks failing in the adverse scenario of the 2014 stress tests far exceeded the results of previous tests. Twenty-four banks failed with a capital shortfall under the adverse scenario of $€ 24.6$ billion. Another sixteen institutions, including seven in Germany, were left with capital ratios between 5.5 per cent to 7 per cent. After capital raising in 2014, fourteen banks still failed the tests, with a shortfall of $€ 9.5$ billion under the adverse scenario, representing four per cent of total bank assets. While more rigorous that all previous EBA stress tests, the 2014 shortfall was lower than most expectations. ${ }^{32}$

28 'ECB says banks overvalued assets by €48bn'. Financial Times, 26 October 2014.

${ }^{29}$ This list is based in part on: 'Stakes high for Europe's bank stress tests', Financial Times, 22 October 2014.

${ }^{30}$ Rigorous stress tests that build investor confidence could also help to lower the banks' cost of funding. In 2014, Italian banks paid on average 1.1 per cent more deposit than German banks.

31 'Draghi Builds Stress-Test Credibility in ECB Bank Review'. Bloomberg Business, 12 December 2014; available at http://www.bloomberg.com/news/articles/2013-1212/draghi-builds-stress-test-credibility-as-ecb-readies-bank-review; 'Transcript of interview with Danièle Nouy'. Financial Times, 9 February 2014.

32 'Analysts comb the data for clues to banks' health'. Financial Times, 26 October 2014; 'Bank shares lose early gains after ECB stress tests'. Financial Times, 27 October, 2014. 
Third, and most importantly, the tests were expected to encourage capital-raising and facilitate bank restructuring. Banks were given just two weeks to present plans to the ECB following the 26 October publication date and up to a further six to nine months to raise capital to cover shortfalls on the baseline and adverse scenarios respectively. ${ }^{33}$ In part, the credibility of the Comprehensive Assessment on this measure was felt prior to the announcement of the November results. A range of larger euro area banks actively engaged in raising capital levels to avoid having to take corrective action later in the year. Principally, banks issued equity. ${ }^{34}$ However, they also publicly listed subsidiaries; deleveraged by selling portfolios of assets; and sold businesses. Described as the 'announcement effect', when some banks raised capital this increased market pressure on other banks to improve their capital positions, regardless the schedule set out in Basel III and the EU's capital requirements directive (CRDIV). ${ }^{35}$ These pressures paralleled a fortuitous improvement in investor demand for bank equity in 2014 which made failing the stress tests even less acceptable to management and investors. ${ }^{36}$ For its part, the ECB actively encouraged banks to take advantage of favourable market conditions to issue equity. ${ }^{37}$ In late October, the ECB estimated that banks had raised $€ 57.1$ billion from the start of the year (ECB 2014e). ${ }^{38}$ To take but one major example, Deutsche Bank raised 8.5 billion with a June equity issue to prepare itself for the AQR. However, a full assessment of this measure of credibility could be detected only following a period of significant writedowns - effectively a further clean-up - in the months following the November results.

The twenty-five (fourteen after earlier capital raising in 2014) named banks that failed the Comprehensive Assessment were largely expected. ${ }^{39}$ Nonetheless, after a brief rise, bank shares indexes dropped significantly. ${ }^{40}$ Most bank analysts expected slow growth in bank lending as a large number of institutions would continue to boost their capital positions. ${ }^{41}$ Thus, the principal overarching objective of the Comprehensive Assessment - to build stable banking sectors that contribute to economic growth was, at best, to be attained in medium term. ${ }^{42}$ Italian and Greek banks were the most exposed, with respectively nine and four failing, followed by three Austrian banks and two from each of Cyprus, Slovenia, and Spain. Italian banks were responsible for a quarter of the total over-valued assets, just less than one per cent of their risk-weighted assets. Greek banks were responsible for $€ 7.6$ billion of the total over-valued assets, or almost 4 per cent of their risk-weighted assets. Once capital injections in early 2014

33 'ECB to give two-week deadline for banks to plan for shortfalls'. Financial Times, 17 July 2014. BdB, the German banking association, criticized the two-week deadline for being too short.

34 'EU banks binge on capital to avoid stress test failure'. Financial Times, 6 May 2014.

35 'European banks raise capital ahead of stress tests'. Financial Times, 3 July 2014.

36 'European banks raise capital ahead of stress tests'. Financial Times, 3 July 2014.

37 'EU banks urged to grasp chance to raise capital'. Financial Times, 24 April 2014.

38 'Analysts comb the data for clues to banks' health'. Financial Times, 26 October 2014.

${ }^{39}$ For a detailed analysis of the results of the Comprehensive Assessment, see 'LEX review European banks after the AQR'. Financial Times, 27 October 2014.

40 'Bank shares lose early gains after ECB stress tests'. Financial Times, 27 October, 2014.

${ }^{41}$ Ibid.

42 'Bank stress tests fail to tackle deflation spectre'. Financial Times, 27 October, 2014. 
were taken into account, four Italian banks still faced shortfalls including the country's third and fourth largest institutions: the Monte dei Paschi di Siena (MPS) and Banco Popolare. MPS, which needed to cover a shortfall of $€ 2.1$ billion, ${ }^{43}$ was the largest failure of the Comprehensive Assessment. Only one German bank failed - Münchener Hypothekenbank — but it had raised sufficient capital in 2014 to avoid additional capital action. German banks would have to lower the value of their assets by $€ 6.7$ billion while French banks would only have to do so by $€ 5.6$ billion.

Italian banks were hit particularly hard by the harmonized definition of non-performing loans. In 2014, bad loans totalled $€ 160$ billion - more than double their level in 2010 — and they were expected to rise to nearly $€ 1200$ billion in $2015 .{ }^{44}$ About seventeen per cent of Italian bank loans - $€ 333$ billion - were nonperforming, according to the International Monetary Fund. ${ }^{45}$ The Italian government responded to the comprehensive assessment by considering the possibility to set up a bad bank - that is, a vehicle designed to absorb some of the non-performing loans of the banking sector - as established previously in Spain (the SAREB). ${ }^{46}$ Banks hoped that the establishment of a bad bank would allow them to sell their bad loans at higher prices. ${ }^{47}$

Despite the widespread vote of confidence for the Comprehensive Assessment from a range of credible sources, ${ }^{48}$ there were also critical voices of both the AQR and stress tests and the methodologies used and there were calls for more work to be done to make them more rigorous (de Groen 2014). ${ }^{49}$ The ECB calculations on the basis of riskweighted assets - which rely on the banks' own assessments of risk-weights assigned to assets and the assessment of credit rating agencies - were criticized. Despite improvement over previous stress tests, transparency was deemed to be inadequate with only a limited disclosure of banks' own funds and liability structure (de Groen 2014). The tests ignored massive litigation costs facing banks. ${ }^{50}$ They ignored the tighter definition of capital to be imposed from 2019 which would deduct items such as goodwill and certain tax assets. Including this definition would, according to a Goldman Sachs study and the EBA's own figures, have quadrupled the actual capital shortfall of European banks and doubled the number of banks failing — including four large

${ }^{43}$ The Economist, 26 October 2014. 'MPS vulnerability exposed by ECB'. Financial Times, 26 October 2014.

${ }^{44}$ Reuters, 3 December 2014.

${ }^{45} \mathrm{http} / / /$ www.imf.org/external/pubs/ft/wp/2015/wp1524.pdf. New York Times, 13 February 2015.

${ }^{46}$ New York Times, 13 February 2015.

${ }^{47}$ Ibid.

48 'Better way to check the health of Europe's banks'. Financial Times (27 October 2014). The Financial Times praises the assessment, while noting its flaws, and calls for the repetition of $\mathrm{AQR}$ on an annual basis.

${ }^{49}$ See, for example, Finance Watch (2014). See also 'Post-crisis journey of rebuilding confidence in Europe's banks'. Financial Times, 3 November 2014; 'European StressTest Results Have Isolated Errors, Inconsistencies'. Wall Street Journal, 27 October 2014. The strong position of German banks - including publicly owned Landesbanks - also attracted considerable scepticism. See 'German banks surprise after stress tests'. Financial Times, 26 October 2014.

50 'Bank stress tests fail to tackle deflation spectre'. Financial Times, 27 October, 2014. 
German banks. ${ }^{51}$ Market expectations had already taken on board this reinforced definition. With the Bank of England announcing a new leverage ratio standard at the end of October, ${ }^{52}$ many bank analysts called for the EBA stress tests also to include the overall level of bank borrowing. A team at the Stern School of Business at New York University led by the economist Viral Acharya had developed an alternative methodology - SRISK which takes into account the banks' total balance sheet without regard for risk (Acharya and Steffen 2014). ${ }^{53}$ Applying SRISK found a range of European banks to suffer from worse shortfalls in an adverse scenario. French banks - which the EBA found had no shortfalls in an adverse situation ${ }^{54}$ — were found to have shortfalls of $€ 189$ billion in the Stern School tests, far worse than the larger German and UK banking systems.

\section{Conclusion}

This contribution has discussed the main milestones in the establishment of the SSM in 2014, leading up to 4 November when the mechanism became operational. It has examined SSM credibility in terms of the mechanism's design and specifically the relationship between the ECB and NCAs within the SSM with the objective of consistent euro area supervision. It has been argued that the principal-agent relation between the ECB and the NCAs is likely to contribute to NCA slippage in the supervision of less significant banks, because 'ex-ante' and 'ex-post' controls are not costless measures. Hence there is a trade-off between higher agency costs against limiting of the 'agency loss'. This contribution has also examined SSM credibility in terms of the effectiveness of the ECB's direct supervision of significant banks. In its Comprehensive Assessment of significant banks, the ECB has demonstrated its capacity to make difficult supervisory decisions, as evidenced by the AQR that revealed the poor state of several banks in the euro area, with Italy having the most troubled banks.

There is an interesting parallel between the quest for credibility in the establishment of the ECB / Eurosystem and that concerning the setting up of the SSM. In the first case, the quest for institutional credibility was triggered by the transfer of monetary policy from the national level to the supranational (euro area) level. In the second, this search for credibility was motivated by the transfer of banking supervision from the national to the supranational level (the euro area / BU level). The main institutional difference between these two processes of delegation is that whereas, in the case of monetary integration, the transfer was complete (that is, there was no monetary sovereignty left at the national level) in the SSM the transfer was partly incomplete because the supervision of less significant banks remained principally at the national level, leaving some room for agent shirking. This contribution has focused on the credibility of the institutional design of the SSM and it first major assessment of the solidity of the euro area's banks, which are the only assessments possible at this stage. The credibility of

\footnotetext{
51 'Bank stress tests fail to tackle deflation spectre'. Financial Times, 27 October, 2014. 'Analysts comb the data for clues to banks' health'. Financial Times, 26 October 2014. 52 'Bank stress tests fail to tackle deflation spectre'. Financial Times, 27 October, 2014. 53 'Alternative stress tests find French banks are weakest in Europe'. Financial Times, 27 October 2014.

54 'ECB results show 'solidity' of French banks, says government'. Financial Times, 26 October 2014.
} 
the SSM will be determined by its empirical track record.

\section{References}

Acharya, V. and Steffen, S. (2014) 'Making Sense of the Comprehensive Assessment'. SAFE Policy Letter, No. 32. Available at http://nbnresolving.de/urn:nbn:de:hebis:30:3-350190 (accessed 13 April 2015).

Alexander, K. (2015) 'European Banking Union: A Legal and Institutional Analysis of the Single Supervisory Mechanism and the Single Resolution Mechanism'. European Law Review, 40, 2, pp. 154-187.

Barth, J., Caprio, G. and Levine, R. (2006) Rethinking Bank Regulation: Til Angels Govern. Cambridge: CUP.

Buckley, J., Howarth, D. and Quaglia, L. (2012) 'The Ongoing Struggle to 'Protect' Europe from Its Money Men'. Journal of Common Market Studies, Vol. 50, s1, pp. 99-115.

Bundesbank (2014) 'Launch of the Banking Union: the Single Supervisory Mechanism in Europe', Deutsche Bundesbank Monthly Report, October, pp. 43-64. Available at

https://www.bundesbank.de/Redaktion/EN/Downloads/Publications/Monthly_R eport Articles/2014/2014 10 banking union.pdf? blob=publicationFile (accessed 13 April 2015).

Cini, M. (2000) 'From Soft Law to Hard Law?: Discretion and Rulemaking in the Commission's State Aid Regime'. EUI RSC, 2000/35 (Florence: European University Institute). Available at http://cadmus.eui.eu/bitstream/handle/1814/1675/00 35.pdf?sequence $=1$ (accessed 13 April 2015).

Cosma, H., and Whish, R. (2003) 'Soft Law in the Field of Competition Policy'. European Business Law Review Vol. 14 No. 1, pp. 25-56.

Council (2013) Regulation (EU) No 1024/2013 of 15 October 2013 conferring specific tasks on the European Central Bank concerning policies relating to the prudential supervision of credit institutions. L 287/63, Brussels. Available at http://bit.ly/1dJpPy9 (accessed 13 April 2015)

Council and European Parliament (2010) Regulation (EU) No. 1093/2010 of the European Parliament and of the Council of 24 November 2010 establishing a European Supervisory Authority (European Banking Authority). L 331/12, Brussels. Available at http://bit.ly/1pFzW7h (accessed 13 April 2015).

De Groen, W. P. (2014) 'Was the ECB's Comprehensive Assessment up to standard?'. CEPS Policy Brief 325, 10 November (Brussels: Centre for European Policy Studies). Available at http://www.ceps.eu/system/files/PB\%20No\%20325\%20WPdG\%20ECB\%20Co mprehensive\%20Assessment.pdf (accessed 13 April 2015)

De Groen, W. P. and Lannoo, K. (2014) 'The ECB AQR and the EBA Stress Test: What will the numbers tell?'. CEPS Commentary, 23 October. Available at http://www.ceps.eu/publications/ecb-aqr-and-eba-stress-test-what-willnumbers-tell (accessed 13 April 2015) 
Egeberg, M., and Trondal, J. (2011) 'EU-level agencies: new executive centre formation or vehicles for national control?'. Journal of European Public Policy, Vol. 18, No. 6, pp. 868-87.

Elgie, R. (2002) 'The politics of the European central bank: Principal - agent theory and the democratic deficit'. Journal of European Public Policy 9(2), pp. 186200 .

European Central Bank (2014a) Decision of the European Central Bank of 4 February 2014 identifying the credit institutions that are subject to the Comprehensive Assessment. ECB/2014/3, Frankfurt: ECB. Available at http://www.ecb.europa.eu/pub/pdf/other/en dec 201403 fen.pdf (accessed 13 April 2015).

European Central Bank (2014b) 'Asset Quality Review: Phase 2 Manual'. March, Frankfurt: ECB. Available at https://www.ecb.europa.eu/pub/pdf/other/assetqualityreviewphase2manual2014 03en.pdf?e8cc41ce0e4ee40222cbe148574e4af7 (accessed 13 April 2015).

European Central Bank (2014c) 'Webcast of public hearing on draft ECB SSM Framework Regulation' [video]. February, Frankfurt: ECB. Available at: http://www.ecb.europa.eu/press/tvservices/other/html/webcast 140219.en.html (accessed 13 April 2015).

European Central Bank (2014d) Regulation (EU) No 468/2014 of the European Central Bank of 16 April 2014 establishing the framework for cooperation within the Single Supervisory Mechanism between the European Central Bank and national competent authorities and with national designated authorities (SSM Framework Regulation). ECB/2014/17. Frankfurt: ECB. Available at http://bit.ly/19bRZRT (accessed 13 April 2015).

European Central Bank (2014e) 'Aggregate report on the comprehensive assessment'. October, Frankfurt; ECB. Available at: https://www.ecb.europa.eu/pub/pdf/other/aggregatereportonthecomprehensiveas sessment201410.en.pdf (Accessed 12 Apr. 2015).

European Central Bank (2015) 'Organizational structure at the ECB'. Available at: https://www.bankingsupervision.europa.eu/organisation/structure/html/index.en .html (accessed 13 April 2015).

European Council (2012) 'Council Agrees Position on Single Supervisory Mechanism'. 17739/12, PRESSE 528, 13 December, Brussels. Available at: http://www.consilium.europa.eu/uedocs/cms data/docs/pressdata/en/ecofin/134 265.pdf (accessed 13 April 2015).

Ferran, E. and Babis, V. (2013) 'The European Single Supervisory Mechanism'. Journal of Corporate Law Studies, 13, pp. 255-285.

Ferrarini, G. and Chiarella, L. (2013) 'Common Banking Supervision in the Eurozone: Strengths and Weaknesses'. ECGI - Law Working Paper, No. 223/2013, August 2013. 
Finance Watch (2014) 'EU bank stress tests and AQR show the need for a binding leverage ratio, says Finance Watch'. 29 October. Available at http://www.finance-watch.org/press/press-releases/965 (accessed 13 April 2015)

Goldstein M. and Veron N. (2011) 'Too Big to Fail: The Transatlantic Debate', Working Paper series, WP 11-2, January, Washington DC: Peterson Institute for International Economics. Available at: http://www10.iadb.org/intal/intalcdi/PE/2011/07335.pdf (accessed 13 April 2015).

Grosse Ruse-Khan, H., Jaeger, T. and Kordic, R. (2011) 'The Role of Atypical Acts in EU External Trade and Intellectual Property Policy'. The European Journal of International Law Vol. 21 no. 4, pp. 901-939.

Hodson, D. (2009) 'Reforming EU economic governance: A view from (and on) the principal-agent approach'. Comparative European Politics 7, pp. 455-475.

Holmstrom, B. (1979) 'Moral hazard and observability'. Bell Journal of Economics, Vol. 10, No. 1, (Spring, 1979), pp. 74-91.

Howarth, D. and Quaglia, L. (2013) 'Banking Union as Holy Grail'. Journal of Common Market Studies, Vol. 51, No. S1, pp. 103-123.

Kiewiet, D.R. and McCubbins, M.D. (1991) The Logic of Delegation: Congressional Parties and the Appropriations Process. Chicago: University of Chicago Press.

König, E. (2014) 'The Role of National Supervisors in Banking Union [video]'. Available at: https://www.youtube.com/watch? $=\mathrm{rLHtYOtrqlA}$ (Accessed 13 April 2015).

Masciandaro, D. (2004) 'Central banks or single financial authorities? A political economy approach'. University of Lecce Economics Working Paper No. 47/25.

Masciandaro, D., Nieto, M. and Prast, H. (2007) 'Financial governance of banking supervision'. Documentos de Trabajo N. 0725 (2007), Madrid: Banco de España.

Masciandaro, D. and Pellegrina, L. (2008) 'Politicians, central banks, and the shape of financial supervision architectures'. Journal of Financial Regulation and Compliance, Vol. 16(4), pp. 290-317.

Pollack, M.A. (1997) 'Delegation, agency and agenda setting in the European Community’. International Organization 51(1), pp. 99-134.

Ross, S. (1973) 'The economic theory of agency: The principal's problem'. American Economic Review 12, pp. 134-139.

Schuknecht, L. (2004) 'EU Fiscal Rules: Issues and Lessons from Political Economy'. European Central Bank Working Paper, No. 421, Frankfurt: ECB.

Schuler, M. (2003) 'Incentive problem in Banking Supervision: the European case'. ZEW Discussion Papers, No. 03-62 (Mannheim: ZEW). 
Snyder, F. (1993) 'Soft Law and Institutional Practice in the European Community'. EUI Working Paper Law No. 93/5 (Florence: European University Institute).

Terman, J. (2015) 'Reexamining the Assumptions of Bureaucratic Behavior'. Journal of Public Administration Research and Theory, DOI: 10.1093/jopart/muu087, 5 February.

Terpan, F. (2015) 'Soft law in the European Union: the changing nature of EU law'. European Law Journal, Vol. 21, Issue 1, pp. 68-96.

Thatcher, M. and Stone Sweet, A. (2002) 'Theory and practices of delegation to nonmajoritarian institutions'. West European Politics Vol. 25, No. 1, pp. 1-22.

Thatcher, M. (2011) 'The creation of European regulatory agencies and its limits: a comparative analysis of European delegation'. Journal of European Public Policy, Vol. 18, No. 6, pp. 790-809.

Van Rompuy, H. (2012) 'Towards and Genuine Economic and Monetary Union: Report by President of the European Council Herman Van Rompuy'. EUCO 120/12, PRESSE 296, PR PCE 102; Brussels, 26 June. Available at http://s3.documentcloud.org/documents/373846/towards-a-genuine-economicand-monetary-union.pdf (accessed 13 April 2015).

Waterman, R.W. and Meier K.J. (1998) 'Principal-agent models: an expansion?'. Journal of public administration research and theory, Vol. 8, No. 2, pp. 173-202.

Weingast, B.R. and Moran, M.J. (1983) 'Bureaucratic discretion or Congressional control?'. Journal of Political Economy 91, pp. 765-800.

Wymeersch, E. (2014) 'The Single Supervisory Mechanism or 'SSM', Part One of the Banking Union'. ECGI - Law Working Paper No. 240/014, February 2014. 